\title{
Synthesis of 4-(4-Hydrazinylphenoxy)phthalonitrile and Phthalonitriles on Its Basis Containing $N$-Heterocycles
}

\author{
Andrey V. Ziminov, ${ }^{@}$ Dariya I. Pudova, Anna I. Kolganova, Mark A. Stretovich, \\ Marina A. Furman, and Stanislav M. Ramsh \\ Saint-Petersburg State Institute of Technology (Technical University), 190013 Saint-Petersburg, Russian Federation \\ ${ }^{\circledR}$ Corresponding authorE-mail: ziminov@inbox.ru
}

\begin{abstract}
The synthesis of the novel 4-(4-hydrazinylphenoxy)phthalonitrile was carried out for the first time by nucleophilic aromatic displacement of nitro group in 4-nitrophthalonitrile to aminophenoxy fragment with following diazotization of amino group and reduction of diazo intermediate. The novel phthalonitriles containing substituted pyrazole or pyrazolone fragments were obtained by reaction of 4-(4-hydrazinylphenoxy)phthalonitrile with different 1,3-dicarbonyl compounds. The structures of the compounds obtained were characterized by IR and ${ }^{1} H$ NMR spectroscopy.
\end{abstract}

Keywords: Phthalonitrile, hydrazine, pyrazole, pyrazolone, IR, ${ }^{1} \mathrm{H}$ NMR spectroscopy.

\section{Синтез 4-(4-гидразинилфенокси)фталонитрила и фталонитрилов на его основе, содержащих $N$-гетероциклы}

\author{
А. В. Зиминов, ${ }^{@}$ А. И. Пудова, А. И. Колганова, М. А. Стретович, М. А. Фурман, \\ C. М. Рамш \\ Санкт-Петербургский государственный технологический институт (технический университет), \\ 190013 Санкт-Петербург, Российская Федерация \\ @E-mail:ziminov@inbox.ru
}

\begin{abstract}
Впервые осуществлен синтез 4-(4-гидразинилфенокси)фталонитрила путем нуклеофильного ароматического замещееня нитрогруппь в 4-нитрофталонитриле на аминофеноксильный фрагмент, диазотирования аминогруппь и восстановления промежуточного диазосоединения. Новые фталонитриль, содержащие пиразольный или пиразолоновый фрагменты, были получень взаимодействием 4-(4-гидразинилфенокси) фталонитрила с различными 1,3-дикарбонильными соединениями. Структура полученных соединений была подтверждена при помощи ИК ${ }^{1}{ }^{1}$ Н ЯМР спектроскопии.
\end{abstract}

Ключевые слова: Фталонитрил, гидразин, пиразол, пиразолон, ИК, ${ }^{1} \mathrm{H}$ ЯМР спектроскопия. 


\section{Introduction}

Metallophthalocyanines are used not only as traditional dyes and pigments, ${ }^{[1,2]}$ but also, thanks to the unique physical and chemical properties, as photocatalysts, ${ }^{[3]}$ semiconductor materials, ${ }^{[4,5]}$ photosensitizers for photodynamic therapy of cancer, ${ }^{[6-10]}$ in optoelectronics. ${ }^{[11]}$ Introduction of substituents in phthalocyanine enhances solubility of the macroheterocycle in many organic solvents and gives them new functional properties. In the last decade intensive increase of number of the papers devoted to phthalocyanines, containing various nitrogen heterocycles is observed..$^{[12-15]} \mathrm{A}$ number of the works devoted to synthesis of phthalocyanines containing the pyrazole fragments are known. These substituents are attached to a linked phthalocyanine macroheterocycle directly, ${ }^{[16]}$ through the methoxy spacer moiety ${ }^{[17]}$ or through oxygen atom spacer moiety. ${ }^{[18]}$ Interest to such substituents is caused by various biological activity of the pyrazole derivatives (antimicrobial, ${ }^{[19]}$ antipyretic, ${ }^{[20]}$ analgesic, ${ }^{[21]}$ antiinflammatory, ${ }^{[22]}$ antiviral ${ }^{[23]}$ properties and others ${ }^{[24]}$ ).

It is known that effective method for synthesis of substituted phthalocyanines is based on the corresponding phthalonitriles. ${ }^{[25-28]}$ Therefore to obtain the novel phthalocyanines with nitrogen containing heterocyclic substituents it is necessary to receive corresponding phthalonitriles containing pyrazole or pyrazolone derivatives. It is known that arylpyrazoles or arylpyrazolones can be synthesized by the reaction of arylhydrazine with different 1,3-dicarbonyl compounds. ${ }^{[29,30]}$ Therefore main task is to obtain phthalonitrile containing a hydrazine fragment.

In this paper we report a method for preparation of 4-(4-hydrazinylphenoxy)phthalonitrile hydrochloride in a few simple steps starting from 4-nitrophthalonitrile and 4-aminophenol as well as procedures for synthesis of some phthalonitrile functional derivatives including 4-(4-(3,5dimethyl-1H-pyrazol-1-yl)phenoxy)phthalonitrile and 4-(4(3-methyl-5-oxo-4,5-dihydro-1H-pyrazol-1-yl)phenoxy) phthalonitrile.

\section{Experimental}

All the reactions were carried out with dry, freshly distilled solvents. 4-Nitrophthalonitrile was purchased from Acros organics. The melting points were determined in capillaries and were not corrected. The individuality of the products was monitored by thin layer chromatography (TLC) on Silufol UV-254 plates and compounds visualized by exposure to UV light. The ${ }^{1} \mathrm{H}$ NMR spectra were recorded on a Bruker AVANCE $400 \mathrm{MHz}$ spectrometer using DMSO- $d_{6}$ as the solvent. The chemical shifts are expressed in $\delta \mathrm{ppm}$. The IR spectra were recorded in the range $4000-400 \mathrm{~cm}^{-1}$ as $\mathrm{KBr}$ pellets on a Shimadzu FTIR-8400S spectrophotometer. Spectral data of phthalonitriles 3-6 are given in Tables 1 and 2. Elemental analyses were carried out on a Leco CHNS(O) 942 Analyzer.

4-(4-Aminophenoxy)phthalonitrile (3). A mixture of 4-nitrophthalonitrile (1) (2.392 g, $10 \mathrm{mmol})$, 4-aminophenol (2) (3.162 g, $29 \mathrm{mmol})$ and anhydrous DMF ( $25 \mathrm{ml})$ was added into a $100 \mathrm{ml}$ single-necked flask and stirred at room temperature. Powdered anhydrous $\mathrm{K}_{2} \mathrm{CO}_{3}(4.01 \mathrm{~g}, 29 \mathrm{mmol})$ was added to the reaction mixture in four equal portions at $15 \mathrm{~min}$ intervals with efficient stirring and then the reaction mixture was stirred at the same temperature for 3 days. Finish of the reaction was observed by TLC. The reaction mixture was vacuum-filtered from inorganic impurities and then was poured into $200 \mathrm{ml}$ of water. The dark yellow solid was vacuum-filtered, washed with water $(500 \mathrm{ml})$ and was dried under vacuum. The product was further purified by column chromatography on silicagel L (40-100 mesh), using 50\% ethyl acetate in hexane as eluant. The solvents were dried using rotary evaporator to give yellow solid. Yield: $1.519 \mathrm{~g},(47 \%), \mathrm{mp}$ 126-128 ${ }^{\circ} \mathrm{C}, \mathrm{R}_{\mathrm{f}}=0.67$ (ethyl acetate/hexane 1:1). Anal. calc. for $\mathrm{C}_{14} \mathrm{H}_{9} \mathrm{~N}_{3} \mathrm{O}$ : C, 71.48; H, 3.86; N, 17.86. Found: C, 71.39; H, 4.18; $\mathrm{N}, 18.08$.

4-(4-Hydrazinylphenoxy)phthalonitrile hydrochloride (4). An ice-cold solution of sodium nitrite (1.49 g, $21.6 \mathrm{mmol})$ in water $(7.6 \mathrm{ml})$ was added dropwise to an ice-cold solution of phthalonitrile 3 (2.54 g, $10.8 \mathrm{mmol})$ in conc. $\mathrm{HCl}(22 \mathrm{ml})$ over 15 min. The reaction mixture was then cooled to $0-5{ }^{\circ} \mathrm{C}$ and stirred for $1 \mathrm{~h}$. Urea $(0.65 \mathrm{~g}, 10.8 \mathrm{mmol})$ was added portion wise to the reaction mixture, over a $10 \mathrm{~min}$ period. Then a solution of tin(II) chloride dihydrate $(9.78 \mathrm{~g}, 43.2 \mathrm{mmol})$ in conc. $\mathrm{HCl}(8 \mathrm{ml})$ was added dropwise to the reaction mixture over a $20 \mathrm{~min}$ period whilst maintaining the temperature below $0-5{ }^{\circ} \mathrm{C}$. The reaction mixture was stirred at $0{ }^{\circ} \mathrm{C}$ for $1 \mathrm{~h}$. The end of the reaction was observed by absence of reaction azocoupling between reaction mixture and 2-naphthol. Then water $(25 \mathrm{ml})$ was added to the reaction mixture. The light yellow precipitate was vacuum-filtered. The product was further purified by recrystallized from hot water with a few drops of conc. $\mathrm{HCl}$ to afford pure compound $\mathbf{4}$ as light yellow solid. Yield: $1.477 \mathrm{~g},(58 \%), \mathrm{mp} 190-192{ }^{\circ} \mathrm{C}$. Anal. calc. for $\mathrm{C}_{14} \mathrm{H}_{11} \mathrm{ClN}_{4} \mathrm{O}: \mathrm{C}$, 58.65; H, 3.87; N, 19.54. Found: C, 58.66; H, 3.58; N, 19.74 .

4-(4-(3,5-Dimethyl-1H-pyrazol-1-yl)phenoxy)phthalonitrile (5). A mixture of phthalonitrile $4(0.72 \mathrm{~g}, 2.51 \mathrm{mmol})$, ethanol $(10 \mathrm{ml})$ and pentane-2,5-dione $(0.264 \mathrm{~g}, 2.64 \mathrm{mmol})$ was added into a single-necked flask. The flask was equipped with a calcium chloride guard tube. The reaction mixture was stirred on a magnetic stitter at reflux for $8 \mathrm{~h}$. Finish of the reaction observed by TLC. After completion of the reaction the solvent was evaporated under reduced pressure and the resulting solid was purified by column chromatography on silicagel L (40-100 mesh) using chloroform as eluent. Light brown solid. Yield: $0.679 \mathrm{~g},(86 \%)$, mp 97-98 ${ }^{\circ} \mathrm{C}$, $\mathrm{R}_{\mathrm{f}}=0.48$ (ethyl acetate/hexane 1:1). Anal. calc. for $\mathrm{C}_{19} \mathrm{H}_{14} \mathrm{~N}_{4} \mathrm{O}: \mathrm{C}$, 72.60; H, 4.49; N, 17.82. Found: C, 72.22; H, 3.99; N, 18.03 .

4-(4-(3-Methyl-5-oxo-4,5-dihydro-1H-pyrazol-1-yl)phenoxy) phthalonitrile (6). A mixture of phthalonitrile 4 (0.6 g, $2.09 \mathrm{mmol})$, ethanol $(10 \mathrm{ml})$ and ethyl acetoacetate $(0.285 \mathrm{~g}, 2.19 \mathrm{mmol})$ was added into a single-necked flask. The flask was equipped with a calcium chloride guard tube. The reaction mixture was stirred on a magnetic stitter at reflux for $12 \mathrm{~h}$. After completion of the reaction mixture was cooled to $0-5{ }^{\circ} \mathrm{C}$. The light yellow precipitate was vacuum-filtered. The resulting solid was purified by column chromatography on silicagel L (40-100 mesh), using chloroform as eluant. Light yellow solid. Yield: $0.25 \mathrm{~g},(45.5 \%)$, mp 93-94 ${ }^{\circ} \mathrm{C}$. Anal. calc. for $\mathrm{C}_{18} \mathrm{H}_{12} \mathrm{~N}_{4} \mathrm{O}_{2}: \mathrm{C}, 68.35 ; \mathrm{H}, 3.82 ; \mathrm{N}, 17.71$. Found: $\mathrm{C}$, $68.02 ; \mathrm{H}, 4.01 ; \mathrm{N}, 17.35$

\section{Results and Discussion}

\section{Synthesis}

The synthetic pathway to the novel compounds is shown in Scheme 1. The starting compound for synthesis of novel phthalonitrile $\mathbf{4}$ containing hydrazine group was phthalonitrile 3 . The preparation of phthalonitrile derivative $\mathbf{3}$ was achieved from the reaction of 4-nitrophthalonitrile $\mathbf{1}$ and 4-aminophenol 2 in presence of anhydrous $\mathrm{K}_{2} \mathrm{CO}_{3}$ as a base in DMF at room temperature for 3 days. It presents the base catalyzed nucleophilic aromatic nitro displacement of 4-nitrophthalonitrile with $O$-nucleophile 2 . The phthalonitrile 
4 was synthesized from phthalonitrile 3 through two steps: diazotization 3 by $\mathrm{NaNO}_{2}$ in concentrated $\mathrm{HCl}$ and reduction diazo intermediate by $\mathrm{SnCl}_{2}$ analogous to (4-phenoxyphenyl) hydrazine synthesis as described in. ${ }^{[31]}$ An order of addition of reagents was very important to high yield of a product. We revealed that it is necessary to add solution of reducing reagent to a reaction mixture. The nature of reducing reagent also plays an important role in the reaction. When the intermediate was reduced by $\mathrm{SnCl}_{2}$, an almost quantitative yield of product was obtained. Use of $\mathrm{Na}_{2} \mathrm{~S}_{2} \mathrm{O}_{3}$ as reducing reagent led to the lower yields. ${ }^{[32]}$ It should be noted that 4-(4-hydrazinylphenoxy)phthalonitrile is unstable on air and it needs to be converted in situ to its hydrochloride. So after boiling in hot water phthalonitrile $\mathbf{4}$ was crystallized by addition of several drops of conc. $\mathrm{HCl}$.

The novel phthalonitriles containing pyrazole $\mathbf{5}$ or pyrazolone 6 substituents were obtained by reaction of phthalonitrile 4 with different 1,3-dicarbonyl compounds (Scheme 1). The one-pot synthesis of $\mathbf{5}$ was carried out by the condensation-cyclization reaction between phthalonitrile 4 and pentane-2,5-dione under reflux in ethanol for $8 \mathrm{~h}$. The one-pot synthesis of $\mathbf{6}$ was carried out by the condensationcyclization reaction between phthalonitrile $\mathbf{4}$ and ethyl acetoacetate under reflux in ethanol for $12 \mathrm{~h}$. This method is easy to perform and requires available $\beta$-diketones to give the products in high or moderate yields $(86 \%$ for $\mathbf{5}$ and $45 \%$ for 6 ). The structures of novel compounds have been characterized by IR (Table 1) and ${ }^{1} \mathrm{H}$ NMR (Table 2) spectroscopy.

\section{IR Spectra of the Synthesized Phthalonitriles}

The observed IR frequencies and approximate assignments shown in Table 1 have been divided into three main spectral regions: $3600-2000 \mathrm{~cm}^{-1}, 1700-1000 \mathrm{~cm}^{-1}$, and $1000-700 \mathrm{~cm}^{-1}$.

$3600-2000 \mathrm{~cm}^{-1}$ region. In the IR spectrum of phthalonitrile 3 disappear the bands of stretching vibrations of $-\mathrm{OH}$ group of 4-aminophenol 2, as well as characteristic bands stretching/bending vibrations of $-\mathrm{NO}_{2}$ group of phthalonitrile 1. At the same time for phthalonitrile 3 the two bands of asymmetric and symmetric stretching vibrations of primary amino group at 3455 and $3376 \mathrm{~cm}^{-1}$ appear. For phthalonitrile 4 these bands disappear, but one band of stretching vibration of secondary amino group at $3314 \mathrm{~cm}^{-1}$ and the broad bands of stretching vibrations of quaternized amino group at 2809<smiles>N#Cc1ccc([N+](=O)[O-])cc1C#N</smiles>

1<smiles>Nc1ccc(O)cc1</smiles>

2<smiles>CCC(C)(C)C</smiles>

3<smiles>C#CCCC</smiles><smiles>N#Cc1ccc(Oc2ccc(NN)cc2)cc1C#N</smiles>
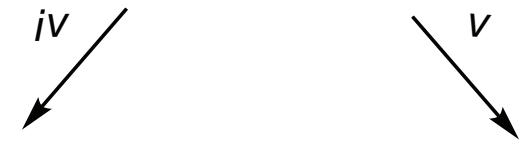<smiles>Cc1cc(C)n(-c2ccc(Oc3ccc(C#N)c(C#N)c3)cc2)n1</smiles>

5<smiles>CC1=NN(c2ccc(Oc3ccc(C#N)c(C#N)c3)cc2)C(=O)C1</smiles>

6

Reagents and conditions: $i$ ) $\mathrm{K}_{2} \mathrm{CO}_{3}$, DMF, r.t.; ii) $\mathrm{NaNo}_{2}, \mathrm{HCl}, 0{ }^{\circ} \mathrm{C}$; iii) $\mathrm{SnCl}_{2}, \mathrm{HCl}, 0{ }^{\circ} \mathrm{C}$;

iv) 2,4-pentanedione, EtOH, reflux; v) Ethyl acetoacetate, EtOH, reflux.

Scheme 1. 
Table 1. The infrared spectral data for the synthesised phthalonitriles and their approximate assignments.

\begin{tabular}{|c|c|c|c|c|}
\hline \multicolumn{4}{|c|}{ Phthalonitrile } & \multirow{2}{*}{ Intensity and band assignments* } \\
\hline 3 & 4 & 5 & 6 & \\
\hline 3455,3376 & - & - & - & $\mathrm{m}, v_{\mathrm{as}}, v_{\mathrm{s}}\left(-\mathrm{NH}_{2}\right)$ \\
\hline- & 3314 & - & - & $\mathrm{m}, v(-\mathrm{NH}-)$ \\
\hline - & 2809,2629 & - & - & $\mathrm{w}, v\left(-\mathrm{NH}_{3}^{+}\right)$ \\
\hline 3078,3046 & 3058,3031 & 3063,3036 & 3081 & $\mathrm{~W}, v\left(\mathrm{C}_{\mathrm{Ar}}-\mathrm{H}\right)$ \\
\hline- & - & 2982,2923 & 2970,2878 & $\mathrm{w}, v_{\mathrm{as}}, v_{\mathrm{s}}\left(-\mathrm{CH}_{3}\right)$ \\
\hline- & - & - & 2926,2803 & $\mathrm{w}, \mathrm{v}_{\mathrm{as}}, \mathrm{v}_{\mathrm{s}}\left(-\mathrm{CH}_{2}-\right)$ \\
\hline 2236 & 2229 & 2230 & 2231 & $\mathrm{~m}, v(-\mathrm{CN})$ \\
\hline- & - & - & 1631 & $\mathrm{~m}, v(\mathrm{C}=\mathrm{O})$ \\
\hline $\begin{array}{l}1598,1562 \\
1510,1486\end{array}$ & $\begin{array}{l}1589,1565 \\
1514,1486\end{array}$ & $\begin{array}{l}1593,1559 \\
1509,1488\end{array}$ & $\begin{array}{l}1602,1591 \\
1503,1492\end{array}$ & $\mathrm{~m}, v\left(\mathrm{C}_{\mathrm{Ar}}=\mathrm{C}_{\mathrm{Ar}}\right)$ \\
\hline- & - & 1421,1362 & 1407,1367 & $\mathrm{~m}, v\left(\mathrm{C}_{\mathrm{Ar}}=\mathrm{N}\right)$ \\
\hline 1283 & 1307,1277 & 1307,1278 & 1312,1276 & $\mathrm{~s}, v\left(\mathrm{C}_{\mathrm{Ar}}-\mathrm{N}\right)$ \\
\hline 1253 & 1253 & 1250 & 1245 & $\mathrm{~s}, v\left(\mathrm{C}_{\mathrm{Ar}}-\mathrm{O}-\mathrm{C}_{\mathrm{Ar}}\right)$ \\
\hline 1205,1011 & $\begin{array}{l}1215,1174, \\
1114,1013\end{array}$ & $\begin{array}{l}1213,1170 \\
1113,1008\end{array}$ & $\begin{array}{l}1207,1135, \\
1102,1009\end{array}$ & $\mathrm{~m}, \delta$ (in plane $\left.\mathrm{C}_{\mathrm{Ar}}-\mathrm{H}\right)$ \\
\hline 1088 & 1083 & 1093 & 1087 & $\mathrm{~m}, \delta\left(\mathrm{C}_{\mathrm{Ar}}-\mathrm{O}-\mathrm{C}_{\mathrm{Ar}}\right)$ \\
\hline 947 & 948 & 951 & 953 & stretching vibrations of benzene fragments \\
\hline 895,836 & 909,838 & 898,832 & 845,837 & $\mathrm{~m}, \delta$ (out of plane $\mathrm{C}_{\mathrm{Ar}}-\mathrm{H}$ ) \\
\hline- & - & 795 & 784,714 & $\mathrm{~m}, \delta\left(\mathrm{C}_{\mathrm{Alk}}-\mathrm{H}\right)$ \\
\hline
\end{tabular}

$* \mathrm{w}$ - weak; $\mathrm{s}$ - strong, $\mathrm{m}$ - medium, $v$ - stretching vibration, $\delta$ - bending vibration

and $2629 \mathrm{~cm}^{-1}$ appear. $^{[33]}$ In the case of phthalonitriles containing pyrazole derivatives $\mathbf{5}$ and $\mathbf{6}$ these bands disappear. For phthalonitrile $\mathbf{5}$ the bands of asymmetric and symmetric stretching vibrations of $-\mathrm{CH}_{3}$ groups appear as well as for phthalonitrile 6 appear the bands of asymmetric and symmetric stretching vibrations of $-\mathrm{CH}_{3}$ and $-\mathrm{CH}_{2}-$ groups. For all phthalonitriles a band of stretching vibrations of nitrile groups appears in the range of 2236-2229 $\mathrm{cm}^{-1}$.

$1700-1000 \mathrm{~cm}^{-1}$ region. For all phthalonitriles the characteristic bands of stretching vibrations of double-bond in benzene ring appear in the range of $1600-1480 \mathrm{~cm}^{-1}$ and the bands of stretching and bending vibrations of $\mathrm{C}-\mathrm{O}-\mathrm{C}$ fragment appear at $1253-1245 \mathrm{~cm}^{-1}$ and 1093-1083 $\mathrm{cm}^{-1}$ respectively. The bands of stretching vibrations of doublebond $-\mathrm{C}=\mathrm{N}-$ in heterocycle appear for both phthalonitriles 5 and $\mathbf{6}$. Also for phthalonitrile $\mathbf{6}$ the characteristic bands of stretching vibrations of $\mathrm{C}=\mathrm{O}$ bond appear at $1631 \mathrm{~cm}^{-1}$. The bands due to the in plane bending of vibrations of aromatic $\mathrm{C}-\mathrm{H}$ groups appear in the $1215-1008 \mathrm{~cm}^{-1}$ range.

$1000-700 \mathrm{~cm}^{-1}$ region. The very characteristic bands in $909-832 \mathrm{~cm}^{-1}$ range due to the out-of-plane bending vibrations of aromatic $\mathrm{C}-\mathrm{H}$ in 1,4- and 1,2,4-substituted benzene rings were observed. ${ }^{[33]}$ For phthalonitriles $\mathbf{5}$ and $\mathbf{6}$ the bands of bending vibrations of $-\mathrm{CH}_{3}$ and $-\mathrm{CH}_{2}-$ groups appear in the range $795-714 \mathrm{~cm}^{-1}$.

\section{${ }^{1} H$ NMR Spectra of the Synthesized Phthalonitriles}

In the ${ }^{1} \mathrm{H}$ NMR spectra of all synthesized phthalonitriles the signals of protons of nitrile substituted benzene rings $\left(\mathrm{H}^{1}, \mathrm{H}^{2}\right.$ and $\left.\mathrm{H}^{3}\right)$ possess characteristic AMX spin system and appear at 8.02-8.09, 7.26-7.45 and 7.56-7.77 ppm respectively. The signal of proton $\mathrm{H}^{1}$ is split into doublet with spin-spin coupling constant typical to phenyl protons at the ortho position. The signal of proton $\mathrm{H}^{3}$ is split into doublet with spin-spin coupling constant typical to phenyl protons at the meta position. The signal of proton $\mathrm{H}^{2}$ is split into double of doublets. Various substituents slightly influence on location of signals of protons $\mathrm{H}^{1}, \mathrm{H}^{2}$ and $\mathrm{H}^{3}$ that can be explained to the lack of conjugation between substituents and nitrile substituted benzene rings.

The signals of protons of benzene rings $\left(\mathrm{H}^{4}, \mathrm{H}^{4}\right.$ and $\left.\mathrm{H}^{5}, \mathrm{H}^{5^{\prime}}\right)$ possess characteristic $\mathrm{AA}^{\prime} \mathrm{XX}$ ' spin system and split into doublet. Electronic effects of substituents have a large influence on these signals. In the ${ }^{1} \mathrm{H}$ NMR spectrum of phthalonitrile 4 the proton signals of $-\mathrm{NH}_{3}^{+}$and - $\mathrm{NH}-$ groups appear as broad singlets at 10.33 and 8.43 respectively. The signals of protons of benzene rings are shifted to the low field region and appear as multiplet at $7.11 \mathrm{ppm}$ due to the strong electron-withdrawing effect of $-\mathrm{NH}-\mathrm{NH}_{3}^{+}$group. In the ${ }^{1} \mathrm{H}$ NMR spectra of phthalonitriles $\mathbf{5}$ and $\mathbf{6}$ the signals of protons of $-\mathrm{CH}_{3}$ and $-\mathrm{CH}_{2}-$ groups appear in high field region at 2.10-2.30 ppm. The signal of protons $\mathrm{H}^{6}$ of phthalonitrile 5 appears as singlet at $6.03 \mathrm{ppm}$.

\section{Conclusions}

In this paper, we presented simple method of synthesis of phthalonitriles bearing different nitrogen containing heterocycles based on the reaction of 4-(4-hydrazinylphenoxy)phthalonitrile hydrochloride with some 1,3-dicarbonyl compounds. The novel 4-(4-hydrazinylphenoxy)phthalonitrile and its derivatives 4-(4-(3,5-dimethyl-1H-pyrazol-1-yl) 
Table 2. The ${ }^{1} \mathrm{H}$ NMR spectral data for the synthesized phthalonitriles.

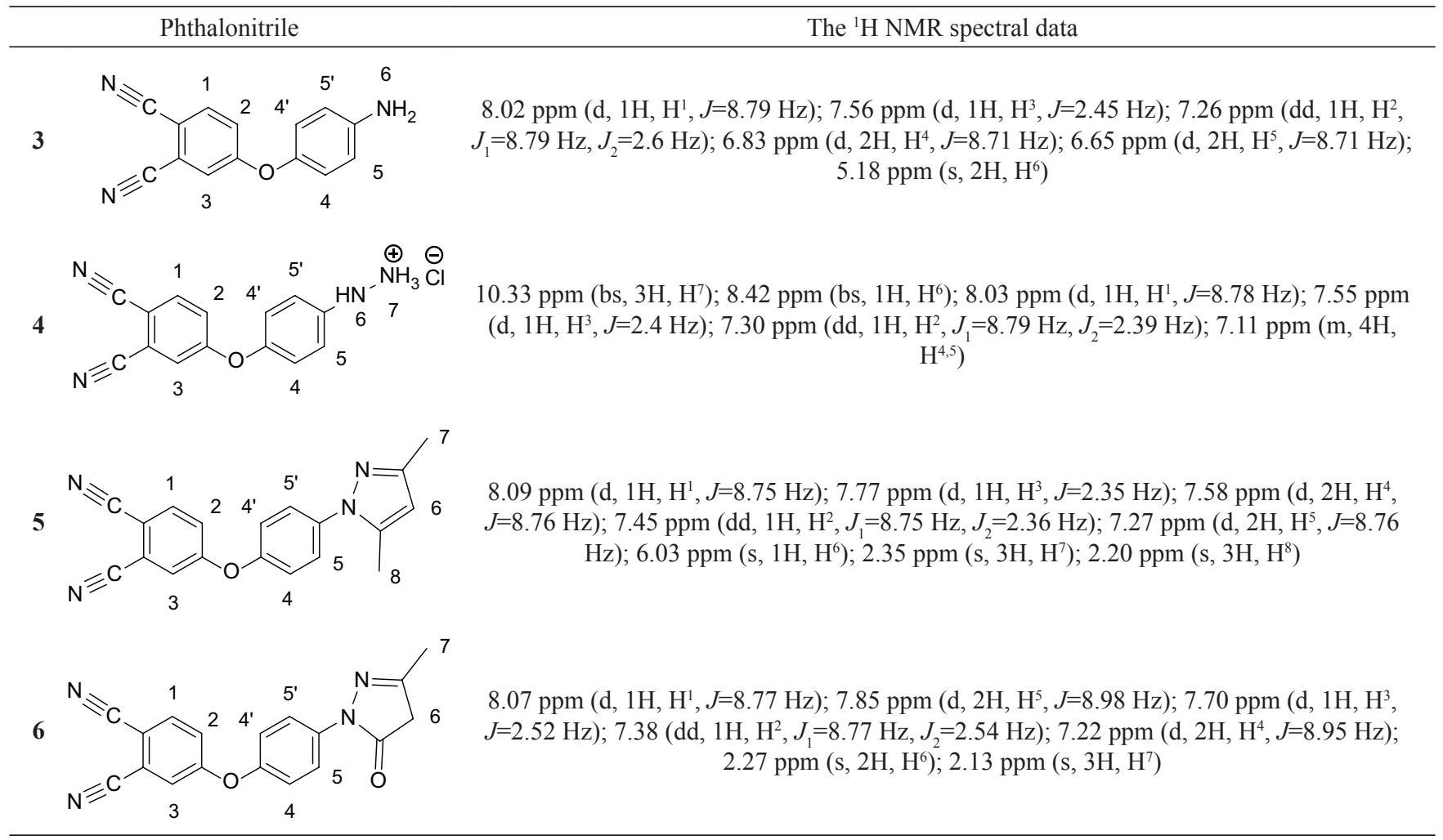

phenoxy)phthalonitrile and 4-(4-(3-methyl-5-oxo-4,5-dihydro-1H-pyrazol-1-yl)phenoxy)phthalonitrile were synthesized and characterized by IR and ${ }^{1} \mathrm{H}$ NMR spectroscopy.

Acknowledgements. This work was supported by the Ministry of Education and Science of the Russian Federation within the Federal target program "Researches and Development in the Priority Directions of Development of a Scientific and Technological Complex of Russia for 2014-2020" for the priority direction "Industry of Nanosystems" (agreement 14.BBB.21.0008) and project part of the state task in the sphere of scientific activity (task No. 10.735.2014/K).

\section{References}

1. Chemistry of Synthetic Dyes (Venkataraman K., Ed.), Leningrad: Khimiya, 1957, Vol. 2, pp. 1278-1304 (in Russ.) [Химия синтетических красителей (Венкатараман К., ред.), Лениград: Химия, 1957, Т. 2, с. 1278-1304].

2. Stepanov B.I. Introduction to the Chemistry and Technology of Organic Dyes, Moscow: Khimiya, 1984. pp. 520-546 (in Russ.) [Степанов Б.И. Введение в химию и технологию органических красителей, М.: Химия, 1984, с. 520-546].

3. Nyokong T., Antunes E. Photochemical and Photophysical Properties of Metallophthalocyanines. In: Handbook of Porphyrin Science (Kadish K.M., Smith K.M., Guilard R., Eds.), Singapore: World Scientific Publishing Co. Pte. Ltd., 2010, Vol. 7, pp. 247-357.

4. McKeown N.B. Phthalocyanine Materials: Synthesis, Structure and Function. Cambridge: Cambridge University Press, 1998. $211 \mathrm{p}$.

5. Zhang Y., Cai X., Bian Y., Jiang J. Organic Semiconductors of Phthalocyanine Compounds for Field Effect Transistors (FETs). In: Functional Phthalocyanine Molecular Materials
(Jiang J., Ed.) Berlin: Springer-Verlag Berlin Heidelberg, 2010, pp. 275-321.

6. Ali H., van Lier J.E. Porphyrins and Phthalocyanines as Photosensitizers and Radiosensitizers. In: Handbook of Porphyrin Science (Kadish K.M., Smith K.M., Guilard R., Eds.), Singapore: World Scientific Publishing Co. Pte. Ltd., 2010, Vol. 4, pp. 1-119.

7. Lukyanets E.A. J. Porphyrins Phthalocyanines 1999, 3, 424432.

8. Bonnett R. Chem. Soc. Rev. 1995, 24, 19-33.

9. Allen C.M., Sharman W.M., van Lier J.E. J. Porphyrins Phthalocyanines 2001, 5, 161-169.

10. Moreira L.M., dos Santos F.V., Lyon J.P., Maftoum-Costa M., Pacheco-Soares C., Soares da Silva N. Aust. J. Chem. 2008 $61,741-754$.

11. Martinez-Diaz M.V., Torres T. On the Significance of Phthalocyanines in Solar Cells. In: Handbook of Porphyrin Science (Kadish K.M., Smith K.M., Guilard R., Eds.), Singapore: World Scientific Publishing Co. Pte. Ltd., 2010, Vol. 10, pp. 141-181.

12. Akcay H.T., Piskin M., Demirbas U., Bayrak R., Durmus M., Mentese E., Kantekin H. J. Organomet. Chem. 2013, 745-746, 379-386.

13. Karimi A.R., Bayat F. Tetrahedron Lett. 2013, 54, 45-48.

14. Nas A., Kantekin H., Durmus M., Gumrukcuoglu N. J. Lumin. 2014, 154, 15-21.

15. Bayrak R., Karaoglu K., Unver Y., Sancak K., Dumludag F., Degirmencioglu I. J. Organomet. Chem. 2012, 712, 57-66.

16. Dehe D., Lothschulz C., Thiel W. New J. Chem. 2010, 34, 526532.

17. Bayrak R., Akcay H.T., Durmus M., Degirmencioglu I. $J$. Organomet. Chem. 2011, 696, 3807-3815.

18. Kulinich V.P., Badaukaite R.A., Tikhomirov T.V., Shaposhnikov G.P. Russ. J. Gen. Chem. 2013, 83, 744-751.

19. Ramalingam K., Thyvelikakath G.X., Berlin K.D., Chesnul R.W., Brown R.P., Durham N.N., Ealick S.E., Vander Helm D. J. Med. Chem. 1977, 20, 847-850. 
20. Mariappan G., Saha B.P., Sutharson L., Singh A., Garg S., Pandey L., Kumar D. Saudi Pharm. J. 2011, 19, 115-122.

21. Gursoy A., Demiravak S., Capan G., Erol K., Vural K. Eur. J. Med. Chem. 2000, 35, 359-364.

22. Gawad A.N.M., Hassan G.S., Georgey H.H. Med. Chem. Res. 2012, 21, 983-994

23. Rashad A.E., Hegab M.I., Abdel-Megeid R.E., Micky J.A., Abdel-Megeid F.M.E. Bioorg. Med. Chem. 2008, 16, 71027106.

24. Chauhan A., Sharma P.K., Kaushik N. Int. J. ChemTech Res. 2011, 3, 11-17.

25. Sharman W.M., van Lier J.E. Synthesis of Phthalocyanine Precursors. In: Handbook of Porphyrin Science (Kadish K.M., Smith K.M., Guilard R., Eds.), California: Academic Press, 2003, Vol. 15, pp. 1-60.

26. McKeown N.B. The Synthesis of Symmetrical Phthalocyanines. In: Handbook of Porphyrin Science (Kadish K.M., Smith K.M., Guilard R., Eds.), California: Academic Press, 2003, Vol. 15, pp. 61-124.

27. Nemykin V.N., Lukyanets E.A. The Key Role of Peripheral Substituents in the Chemistry of Phthalocyanines. In: Handbook of Porphyrin Science (Kadish K.M., Smith K.M.,
Guilard R., Eds.), Singapore: World Scientific Publishing Co. Pte. Ltd., 2010, Vol. 3, pp. 1-323.

28. Shaposhnikov G.P., Kulinich V.P., Maizlish V.E. Modified Phthalocyanines and Their Structural Analogues. Moscow: Krasand, 2013. 480 p (in Russ.) [Шапошников Г.П, Кулинич В.П., Майзлиш В.Е. Модифицированные фталоцианины и их структурные аналоги. М.: Красанд, 2013. 480 с.]

29. Zelenin K.N., Tugusheva A.R., Yakimovich S.I., Alekseev V.V., Zerova E.V. Chem. Heterocycl. Compd. 2002, 38, 668676.

30. Reddy C.S., Devi M.V., Sunitha M., Nagaraj A. Chem. Pharmaceut. Bull. 2010, 58, 1622-1626.

31. Point V., Kumar P.K.V.P., Marc S., Delorme V., Parsiegla G., Amara S., Carriere F., Buono G., Fotiadu F., Canaan S., Leclaire J., Cavalier J.F. Eur. J. Med. Chem. 2012, 58, 452-463.

32. Hu H., Ge C., Ding L., Zhang A. Molecules 2010, 15, 74727481.

33. Bellamy L.J. The Infra-Red Spectra of Complex Molecules, 2nd Ed., Methuen \& Co., London, 1958 [Беллами Л.Дж. Инфракрасные спектры сложных молекул (пер. с англ., Пентин Ю.А., ред.), М.: Изд-во Иностранной литературы, 1963. 592 c.].

Received 24.07.2014 Accepted 25.08.2014 